\title{
PENGARUH RETURN ON ASSETS, RETURN ON EQUITY, EARNING PER SHARE TERHADAP HARGA SAHAM PADA PERUSAHAAN OTOMOTIF YANG TERDAFTAR BEI
}

\author{
Fangky A. Sorongan
}

Perbanas Institut Jakarta

A R T I C L E I N F O

Keywords: fixed effect, profitabilitas, Return on Assets, Return on Equity, Earning per Share, Stock Price

Kata Kunci: fixed effect, profitabilitas, Return on Assets, Return on Equity, Earning per Share, Harga Saham

\begin{abstract}
The purpose of this study is to analyse the impact of Return on Assets, Return on Equity, and Earning per Share against stocks in automotive companies listed on the Indonesia Stock Exchange. The data used in this study was obtained from the annual company financial statement data of the 20132016 period. The analytical techniques used in this study were the data regression panel. The results of the study using the fixed effect model found that Return on Assets had no significant effect on the stock price, while Return on Equity was negatively and significantly impacted by the share price and the Earning per Share have a positive and significant effecr towards the stock price.
\end{abstract}

Abstrak: Tujuan dari studi ini adalah untuk menganalisis pengaruh dari Return on Assets, Return on Equity, dan Earning per Share terhadap saham pada perusahaan otomotif yang terdaftar di Bursa Efek Indonesia. Data yang digunakan dalam studi ini diperoleh dari data laporan keuangan tahunan perusahaan otomotif periode 2013-2016. Teknik analisis yang digunakan dalam studi ini adalah regresi data panel. Hasil penelitian yang menggunakan model fixed effect menemukan bahwa Return on Assets tidak berpengaruh signifikan terhadap harga saham, sedangkan Return on Equity berpengaruh negatif dan signifikan terhadap harga saham dan Earning per Share berpengaruh positif dan signifikan terhadap harga saham.

Corresponding author:

Fangky.A. Sorongan

f.sorongan@perbanas.id 


\section{Latar Belakang}

\section{PENDAHULUAN}

Pasar modal didefinisikan sebagai pasar untuk berbagai instrumen keuangan (sekuritas) jangka panjang yang bisa diperjual belikan, dalam bentuk hutang maupun modal sendiri, baik yang diterbitkan oleh pemerintah, public autorities, maupun swasta (Husnan, 2006). Pasar modal merupakan sasaran untuk melakukan investasi yaitu memungkinkan para pemodal investor untuk melakukan diversifikasi investasi, membentuk portofolio sesuai dengan risiko yang bersedia mereka tanggung dengan tingkat pengembalian yang diharapkan. Tujuan para pemodal atau investor menanamkan modalnya pada sekuritas saham adalah untuk mendapatkan return (tingkat pengembalian) yang tinggi tapi dengan tingkat risiko tertentu atau mendapatkan return tertentu dengan tingkat risiko yang rendah. Penilaian investor terhadap suatu saham perusahaan diantaranya dengan memperhatikan kinerja perusahaan yang menerbitkan saham. Oleh karena itu return saham sangat penting bagi perusahaan karena digunakan sebagai salah satu pengukur kinerja suatu perusahaan sehingga perusahaan berusaha memperbaiki.

Indonesia memiliki perkembangan yang cukup menakjubkan pada dunia otomotif. Tidak hanya sekedar pernyataan belaka namun hal ini didukung oleh segelintir peneliti yang melakukan analisa terhadap perkembangan otomotif yang ada di Indonesia.

Nilai perusahaan pada dasarnya dapat diukur melalui berbagai parameter dan salah satu parameter yang digunakan adalah harga pasar saham. Harga pasar saham suatu perusahaan dianggap dapat mencerminkan penilaian investor secara keseluruhan atas setiap ekuitas yang dimiliki perusahaan. Hermuningsih dan Wardani (2009) dan Kasmir (2010) menyatakan bahwa nilai suatu perusahaan dapat ditunjukkan dengan harga saham. Dengan demikian memaksimumkan nilai pasar perusahaan sama artinya memaksimumkan nilai pasar saham. Nilai perusahaan yang tinggi akan meningkatkan kepercayaan investor terhadap perusahaan.

Pengukuran dengan Return On Assets menunjukkan kemampuan dari modal yang diinvestasikan dalam keseluruhan aktiva dalam menghasilkan laba. Laba juga dapat diukur melalui Return On Equity perusahaan karena Return On Equity mempunyai hubungan positif dengan perubahan laba. Return On Equity digunakan untuk mengukur efektivitas perusahaan didalam menghasilkan keuntungan dengan memanfaatkan ekuitas yang dimilikinya. Earning per Share mengukur seberapa besar dividen per lembar saham yang akan dibagikan kepada investor setelah dikurangi dengan dividen bagi para pemilik perusahaan. Apabila Earning per Share perusahaan tinggi maka akan banyak investor yang mau membeli saham tersebut sehingga menyebabkan harga saham tinggi.

Kondisi perusahaan otomotif yang mengalami perkembangan pesat akan memicu ketertarikan investor pada pihak perusahaan karena nilainya yang telah meningkat. Peran investor disini sangatlah berpengaruh dalam investasinya terhadap suatu perusahaan, khususnya perusahaan otomotif.

Berdasarkan uraian di atas, peneliti tertarik untuk menguji pengaruh ROA, ROE, EPS terhadap harga saham terhadap harga saham di Perusahaan otomotif yang terdaftar di BEI

\section{TINJAUAN PUSTAKA}

\section{Return on Asset (ROA)}

Gitman dan Zutter (2012:81) menjelaskan Return on Asset adalah rasio yang mengukur keseluruhan efektivitas manajemen dalam menghasilkan keuntungan dengan asset yang tersedia. Semakin tinggi return perusahaan terhadap total asset maka semakin baik.

Menurut Bringham dan Houston (1999:109) berpendapatan bahwa ROA yang besar akan menunjukkan kinerja perusahaan yang baik, karena return yang didapatkan semakin besar. Return yang besar maka akan menarik minat investor untuk menanamkan modalnya pada perusahaan tersebut sehingga selanjutnya akan berdampak pada kenaikan harga saham, Sorongan (2016.)

ROA dapat dirumuskan sebagai berikut:

$$
\mathrm{ROA}=\frac{\text { Laba Bersih }}{\text { Total Asset }} \times 100
$$




\section{Return on Equity (ROE)}

Return on Equity (ROE) adalah salah satu rasio yang digunakan untuk menganalisis profitabilitas perusahaan. Menurut Syamsuddin (2007:64), ROE merupakan salah satu ukur penghasilan bagi pemilik perusahaan. ROE juga dapat memperlihatkan bagaimana perusahaan mengelola ekuitas secara efektif atau rasio yang mengukur keuntungan dari investasi yang telah dilakukan pemilik ekuitas atau pemegang saham (Sawir, 2001).

Return on Equity (ROE) dapat dihitung dengan menggunakan rumus sebagai berikut:

$$
\text { Return on Equity }(R O E)=\frac{\text { Laba Bersih Setelah Pajak }}{\text { Ekuitas }} \times 100 \%
$$

\section{Earning per Share (EPS)}

Earning per Share (EPS) atau laba per lembar saham merupakan pembagian antara laba yng tersedia bagi pemegang saham dengan jumlah yang beredar. Laba per lembar saham menunjukkan kemampuan perusahaan menciptakan laba bagi setiap lembar sahamnya. Priatinah dan Kusuma (2012) mengungkapkan bahwa melalui parameter EPS, investor dapaat mengetahui informasi yang cukup memadai berkaitan dengan perkembangan kinerja perusahaan, terutama kinerja sahamnya. Dengan demikian, EPS dapat digunakan kriteria untuk mengukur keberhasilan manajemen dalam mencapai keuntungan bagi pemegang saham (Kasmir, 2010).

Earning per Share (EPS) dapat dihitung dengan menggunakan rumus sebagai berikut:

$$
\text { Earning per Share }(E P S)=\frac{\text { Laba Bersih Setelah Pajak }}{\text { Jumlah Saham Beredar }}
$$

\section{Kerangka konseptual}

Berdasarkan latar belakang dan tinjauan teoritas yang telah dikemukakan sebelumnya, maka kerangka konseptual dapat digambarkan sebagai berikut :

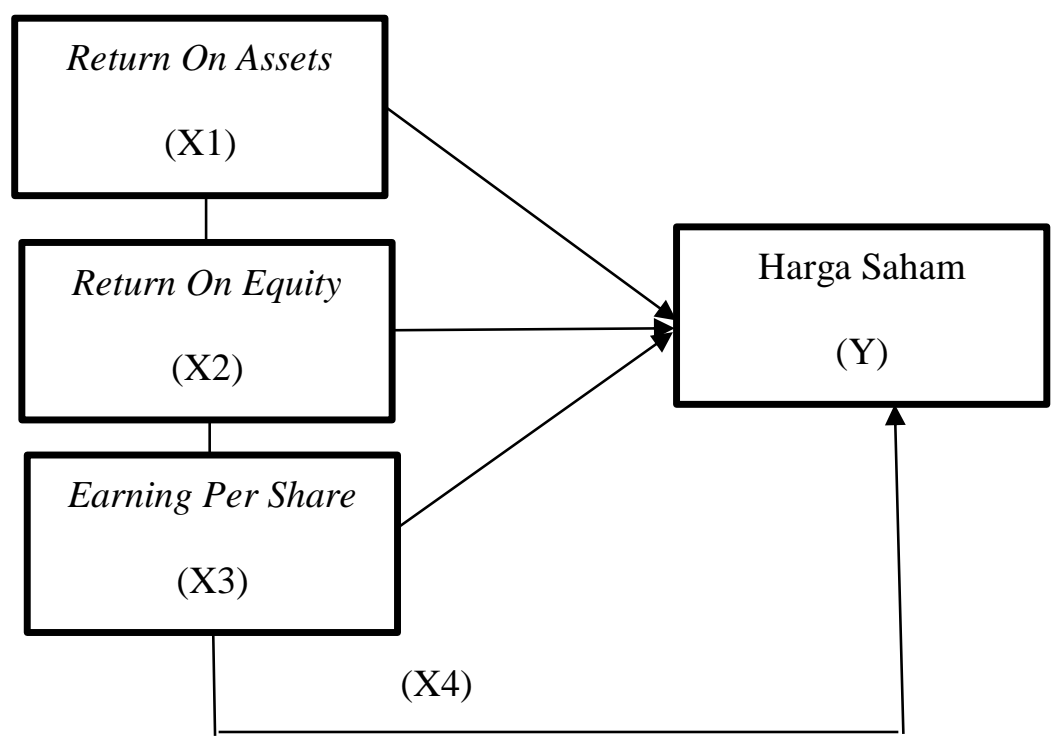

\section{Gambar 1. Kerangka Konseptual}

\section{Hipotesis Penelitian}

Sesuai kerangka pemikiran teoritis yang diungkapkan sebelumnya maka hipotesis yang diajukan dalam penelitian ini adalah: 
H1: diduga Return On Assets (ROA) berpengaruh signifikan terhadap harga saham

H2: diduga Return on Equity (ROE) berpengaruh signifikan terhadap harga saham

H3: diduga Earning per Share (EPS) berpengaruh signifikan terhadap harga saham.

H4: diduga ROA, ROE, dan EPS merupakan model yang layak

\section{Populasi dan Sampel}

\section{METODE PENELITIAN}

Populasi dalam penelitian ini adalah perusahaan otomotif yang terdaftar di Bursa Efek Indonesia (www.idx.co.id) dan dipublikasikan adalah 11 perusahaan pada tahun 2013-2016. Teknik yang digunakan dalam pengambilan sampel dalam penelitian ini adalah purposive sampling yaitu pemilihan sample perusahaan selama periode penelitian berdasarkan kriteria tertentu

\section{Jenis dan Sumber Data}

Data yang digunakan adalah data sekunder yang bersifat kuantitatif mengenai laporan keuangan tahunan dan harga saham penutupan (closing price) tiap perusahaan yang diperoleh dari harga saham pada periode akhir tahun. Data harga saham diambil dari www.yahoofinance.com. Sumber data pada penelitian ini diperoleh dari situs resmi yang dimiliki oleh BEI yaitu www.idx.co.id berupa laporan keuangan dan situs resmi masing-masing perusahaan.

\section{Metode Pengumpulan Data}

Dalam penelitian ini penelitian yang bersifat kuantitatif, penulis menggunakan software berupa Ms.Excel 2016 dan E-Views 9. Penelitian ini menggunakan data panel dikarenakan jumlah objek penelitian lebih dari lima puluh dan dalam waktu empat tahun atau dalam periode $2013-2016$.

\section{Analisis Data Panel}

Menurut Widarjono (2013), persamaan model regresi data panel dapat dirumuskan sebagai berikut:

$$
\text { Yit }=\alpha+\beta 1 X 1 i t+\beta 2 \text { X2it }+\beta 3 \text { X3it }+\varepsilon i
$$

Keterangan:

$\mathrm{Y}=$ Harga Saham

$\alpha=$ Konstanta

$\beta 1-\beta 4=$ Koefisien regresi variabel bebas

$\mathrm{X} 1=$ Return On Assets (ROA)

$\mathrm{X} 2$ = Return On Equity (ROE)

$\mathrm{X} 3=$ Earning per Share (EPS)

$\varepsilon=$ Variabel Pengganggu

$\mathrm{i}=18$ Perusahaan Sampel

$\mathrm{t}=$ Periode observasi $2013-2016$

\section{Hasil Penelitian}

\section{HASIL PENELITIAN DAN PEMBAHASAN}

\section{Analisis Regresi Data Panel}

Berdasarkan berbagai tahapan pengujian data diatas telah terpilih model yang terbaik digunakan adalah fixed effect. Berikut merupakan hasil dari pengujian tersebut:

\section{Tabel 1. Hasil pengujian fixed effect}

Cross-section fixed effects test equation: 
Dependent Variable: LOG(PRICE)

Method: Panel Least Squares

Date: 03/23/18 Time: 01:40

Sample: 20132016

Periods included: 4

Cross-sections included: 11

Total panel (balanced) observations: 44

\begin{tabular}{crlrr}
\hline \hline \multicolumn{1}{c}{ Variable } & Coefficient & Std. Error & t-Statistic & Prob. \\
& & & & \\
(ROA) & 0.242630 & 0.213701 & 1.135373 & 0.2630 \\
(ROE) & -0.403900 & 0.180010 & -2.243761 & 0.0305 \\
(EPS) & 0.684678 & 0.078528 & 8.718893 & 0.0000 \\
$\mathrm{C}$ & 4.751901 & 0.429916 & 11.05308 & 0.0000 \\
\hline \hline & & & 7.611487 \\
R-squared & 0.665404 & Mean dependent var & 1.186719 \\
Adjusted R-squared & 0.640309 & S.D. dependent var & 2.244260 \\
S.E. of regression & 0.711726 & Akaike info criterion & 2.406459 \\
Sum squared resid & 20.26215 & Schwarz criterion & 2.304411 \\
Log likelihood & -45.37373 & Hannan-Quinn criter. & 1.528069 \\
F-statistic & 26.51569 & Durbin-Watson stat & \\
Prob(F-statistic) & 0.000000 & & \\
\hline \hline
\end{tabular}

Sumber: Hasil output Eviews 9

Pada tabel 1 dapat diperoleh persamaan regresi sebagai berikut:

Harga Saham $=4,751901+0,242630$ ROA $-0,403900$ ROE $+0,684678$ EPS $+e$

Dari persamaan diatas dapat disimpulkan beberapa hal yaitu:

1. Nilai konstanta adalah 4,751901 yang memiliki arti bahwa apabila variabel independen (ROA, ROE, dan EPS) nilainya konstan maka harga saham sebesar 4,751901

2. Koefisien variabel ROA sebesar 0,242630 dan bertanda positif. Hal ini akan menunjukkan bahwa setiap kenaikan ROA satu satuan, maka harga saham pun akan naik sebesar 0,242630

3. Koefisien variabel ROE sebesar 0,403900 dan bertanda negatif. Hal ini akan menunjukkan bahwa setiap kenaikan ROE satu satuan, maka harga saham pun akan turun sebesar 0,403900

4. Koefisien variabel EPS sebesar 0,684678 dan bertanda positif. Hal ini akan menunjukkan bahwa setiap kenaikan EPS satu satuan, maka harga saham pun akan naik sebesar 0,684678

\section{Pengujian Hipotesis}

\section{Tabel 2. Hasil Uji T}

Dependent Variable: LOG(PRICE)

Method: Panel Least Squares

Date: 03/23/18 Time: 01:47

Sample: 20132016

Periods included: 4

Cross-sections included: 11

Total panel (balanced) observations: 44 


\begin{tabular}{crrrr}
\hline Variable & Coefficient & Std. Error & t-Statistic & Prob. \\
\hline \hline (ROA) & 0.242630 & 0.213701 & 1.135373 & 0.2630 \\
(ROE) & -0.403900 & 0.180010 & -2.243761 & 0.0305 \\
(EPS) & 0.684678 & 0.078528 & 8.718893 & 0.0000 \\
C & 4.751901 & 0.429916 & 11.05308 & 0.0000 \\
\hline \hline R-squared & 0.665404 & Mean dependent var & 7.611487 \\
Adjusted R-squared & 0.640309 & S.D. dependent var & 1.186719 \\
S.E. of regression & 0.711726 & Akaike info criterion & 2.244260 \\
Sum squared resid & 20.26215 & Schwarz criterion & 2.406459 \\
Log likelihood & -45.37373 & Hannan-Quinn criter. & 2.304411 \\
F-statistic & 26.51569 & Durbin-Watson stat & 1.528069 \\
Prob(F-statistic) & 0.000000 & & \\
\hline \hline
\end{tabular}

Sumber: Hasil output Eviews 9

Berdasarkan hasil dari uji t seperti pada tabel 2 diatas menunjukkan nilai probabilitas ROA yakni 0,2630, yang berarti bahwa nilainya lebih besar dari $\alpha=0,05$. Dari penjelasan tersebut disimpulkan bahwa H0 diterima dan $\mathrm{H} \alpha$ ditolak. Ini berarti variabel ROA tidak memiliki pengaruh signifikan terhadap harga saham.

Pada tabel 2 nilai probabilitas pada variabel ROE sebesar 0,0305 lebih kecil dari $\alpha=0,05$, dengan demikian $\mathrm{H} 0$ ditolak $\mathrm{H} \alpha$ diterima. Artinya bahwa variabel $\mathrm{ROE}$ berpengaruh signifikan terhadap harga saham.

Berdasarkan pada pengujian diatas menunjukkan nilai probabilitas EPS adalah 0,0000 atau lebih kecil dari $\alpha=$ 0,05. H0 ditolak $\mathrm{H} \alpha$ diterima artinya EPS berpengaruh signifikan terhadap harga saham.

\section{Uji Kelayakan Model (uji F)}

Uji kelayakan model digunakan untuk melihat apakah model regresi layak digunakan untuk menjelaskan pengaruh variabel independent secara keseluruhan terhadap variabel dependent. Pada uji kelayakan model ini menggunakan nilai statistik F Pada tabel 2 menunjukkan nilai probabilitas F- statistik sebesar 0,000000 atau lebih kecil dari $\alpha=0,05$ artinya bahwa H0 diterima H1 ditolak. Dengan demikian dapat dinyatakan bahwa ROA, ROE, EPS merupakan model yang layak untuk memberikan pengaruh terhadap harga saham.

\section{Koefisien Determinasi}

Koefisien determinasi atau adjusted $R_{2}$ digunakan untuk melihat seberapa jauh kemampuan model menerangkan variasi variabel independent. Pada tabel 2 memberikan hasil estimasi nilai Adjusted $R$ - squared sebesar 0,640309 atau 64,03\%. Ini berarti nilai harga yang saham mampu dijelaskan atau dipengaruhi oleh variabel independen (ROA, ROE, EPS) sebesar 64,03\% dan sisanya 35,97\% dipengaruhi oleh faktor-faktor lain yang tidak dijelaskan dalam penelitian ini.

\section{Pembahasan}

Pada tabel 2 pengujian uji t dapat diketahui bahwa nilai probabilitas ROA sebesar 0,2630 yang berarti bahwa nilainya lebih kecil dari $\alpha=0,05$. Dari penjelasan tersebut dapat disimpulkan bahwa variabel ROA tidak berpengaruh signifikan terhadap harga saham, sejalan dengan penilitian yang dilakukan oleh Hutapea (2017) yang menyatakan bahwa Return On Assets tidak berpengaruh terhadap harga saham. Hal ini dimungkinkan karena terjadinya perlambatan pertumbuhan ekonomi terutama di tahun 2015 sehingga penjualan otomotif nasional juga mengalami penurunan yang berdampak pada return on assets. Penelitian ini tidak sejalan dengan teori sebelumnya yang dijelaskan Bringham dan Houston (2006:109) berpendapatan bahwa ROA yang besar akan menunjukkan kinerja perusahaan yang baik, karena return yang didapatkan semakin besar. Dengan adanya return yang semakin besar maka akan menarik minat investor untuk menanamkan modalnya pada perusahaan tersebut sehingga selanjutnya akan berdampak pada kenaikan harga saham. Hasil penelitian ini juga tidak sejalan dengan penelitian sebelumnya oleh Sari Puspita Dewi dan Rahmat Hidayat (2014) yang menunjukkan bahwa ROA berpengaruh positif terhadap harga saham. 
Selanjutnya hasil uji t pada ROE memiliki nilai probabilitas 0,0305 yang berarti bahwa nilainya lebih besar dari $\alpha=0,05$ dan thitung sebesar $-2,243761$ artinya bahwa ROE memiliki pengaruh terhadap harga saham. Hasil ROE negatif dikarenakan rata-rata ROE tiap tahunnya mengalami penurunan yang cukup signifikan tetapi harga saham cenderung mengalami kenaikan. Perusahaan dapat menghasilkan keuntungan dengan modal sendiri yang dapat menguntungkan pemegang saham. Sehingga ROE berpengaruh terhadap harga saham. Hasil ini tidak sejalan dengan Mujairi Mi (2015) yang menyatakan bahwa Return On Equity tidak berpengaruh terhadap harga saham.

Hasil tersebut sejalan dengan teori sebelumnya dari Prasetyorini (2013) bahwa apabila terjadi peningkatan terhadap ROE pada beberapa periode berarti terjadi pula kenaikan laba bersih dari perusahaan tersebut. Naiknya laba bersih mengindikasikan bahwa nilai perusahaan juga naik karena akan meningkatkan harga saham. Hal ini juga sejalan dengan penelitian sebelumnya Zunaini (2009) yang menyatakan bahwa ROE berpengaruh negatif dan signifikan terhadap harga saham. Namun hasil hasil penelitian tidak di dukung oleh penelitian Fadrul (2012) yang menyatakan bahwa ROE tidak berpengaruh terhadap harga saham

Berdasarkan hasil uji hipotesis nilai probabilitas EPS 0,0000 nilai tersebut lebih besar dari $\alpha=0,05$. Oleh karena itu dapat disimpulkan bahwa secara parsial EPS berpengaruh terhadap harga saham. Hasil penelitian sejalan dengan penelitian Kashmir (2010), Sunandes (2013) yang menyatakan bahwa EPS berpengaruh signifikan terhadap harga saham. EPS dapat digunakan kriteria untuk mengukur keberhasilan manajemen dalam mencapai keuntungan bagi pemegang saham. Hal ini berarti membuktikan bahwa para investor tertarik dengan EPS yang tinggi karena EPS merupakan jumlah keuntungan yang dapat diperoleh untuk per lembar sahamnya. Semakin tinggi daya tarik para calon investor terhadap saham perusahaan maka nilai saham per lembar tersebut akan naik sehingga berpengaruh positif terhadap harga saham. Hasil dari penelitian ini tidak sejalan dengan Pesiwarissa (2014) dalam penelitiannya menyatakan bahwa EPS tidak berpengaruh terhadap harga saham.

Nilai probabilitas F- statistik sebesar 0,000000 atau lebih kecil dari $\alpha=0,05$ artinya bahwa H0 diterima H1 ditolak. Dengan demikian dapat dinyatakan bahwa ROA, ROE, EPS merupakan model yang layak untuk memberikan pengaruh terhadap harga saham. Hasil estimasi nilai Adjusted $R$ - squared sebesar 0,640309 atau 64,03\%. Ini berarti nilai harga yang saham mampu dijelaskan atau dipengaruhi oleh variabel independen (ROA, ROE, EPS) sebesar 64,03\% dan sisanya 35,97\% dipengaruhi oleh faktor-faktor lain yang tidak dijelaskan dalam penelitian ini.

\section{Kesimpulan}

\section{PENUTUP}

Kesimpulan pada penelitian ini Penelitian adalah bahwa Return on Assets tidak memiliki pengaruh yang signifikan terhadap harga saham. Return on Equity memiliki pengaruh signifikan terhadap harga saham. Perusahaan dapat menghasilkan keuntungan dengan modal sendiri yang dapat menguntungkan pemegang saham. Sehingga ROE berpengaruh terhadap harga saham. Earning per Share memiliki pengaruh signifikan terhadap harga harga saham. Hal ini berarti membuktikan bahwa para investor tertarik dengan EPS yang tinggi karena EPS merupakan jumlah keuntungan yang dapat diperoleh untuk per lembar sahamnya. Semakin tinggi daya tarik para calon investor terhadap saham perusahaan maka nilai saham per lembar tersebut akan naik sehingga berpengaruh positif terhadap harga saham. Return on Assets, Return on Equity dan Earning per Share terhadap harga saham merupakan model yang layak.

\section{Saran}

Berdasarkan kesimpulan pada penelitian ini, maka dapat disampaikan beberapa saran yaitu Peneliti hanya membatasi ruang lingkup penelitian pada variabel Return on Assets (ROA), Return on Equity (ROE) dan Earning per Share (EPS) yang diuji pengaruhnya 64,03\%. terhadap harga saham. kenyataannya masih 35,97\% faktor lain yang mempengaruhi harga saham. (2) Bagi penelitian selanjutnya, dapat menambah variabel dan/atau waktu pengamatan yang diteliti dikarenakan waktu penelitian yang relatif pendek yaitu selama empat tahun.

\section{DAFTAR PUSTAKA}


Aluy, C. A., Tulung, Joy Elly, \& Tasik, H. H. (2017). Pengaruh Keberadaan Wanita Dalam Manajemen Puncak Dan Kepemilikan Manajerial Terhadap Kinerja Keuangan Perbankan (Studi Pada Bank Bumn dan Bank Swasta Nasional Devisa di Indonesia). Jurnal Riset Ekonomi, Manajemen, Bisnis Dan Akuntansi, 5(2).

Bringham, E. F., \& Houston, J, F. (1999). Dasar-Dasar Manajemen Keuangan. Jakarta: Salemba Empat.

Fadrul \& Lebara, Z. (2016). Analisis Pengaruh PER, ROE, DER Terhadap Harga Saham Pada Perusahaan Sub Sektor Otomotif dan Komponen yang Terdaftar di Bursa Efek Indonesia Tahun 2007-2014. Jurnal Akuntansi, Vol.04, No.02

Fahmi, Irham (2012). Analisis Laporan Keuangan. Edisi 2. Bandung: CV Alfabeta

Gitman, Lawrence, J., \& Zutter, C. J. (2012). Principle of Management Finance (Edisi XIII). Pearson International Edition.

Hermuningsih, S \& Wardani, D.K. (2009). Faktor-Faktor yang Mempengaruhi Nilai Perusahaan Pada Perusahaan yang Terdaftar di Bursa Efek Malaysia dan Bursa Efek Indonesia. Jurnal Siasat Bisnis, Volume (13)

Husnan, S. (2006). Dasar - dasar Teori Portofolio dan Sekuritas. Yogyakarta: AMP YKPN.

Hutapea, A.W., Saerang, I. S. \& Tulung, J. E. (2017). Pengaruh ROA, NPM, DER dan TATO Terhadap Harga Saham Industri Otomotif dan Komponen yang Terdaftar di Bursa Efek Indonesia. Jurnal Riset Ekonomi, Manajemen, Bisnis Dan Akuntansi, 5(2). EMBA, Vol.5 No.2 Juni 2017, Hal. 541 - 552,

Kasmir. (2010). Pengantar Manajemen Keuangan. Jakarta : PT Raja Grafindo Indonesia.

Mujairi., M. (2015). Pengaruh Rasio Keuangan Terhadap Harga Saham Pada Perusahaan Otomotif yang Terdaftar di Bursa Efek Indonesia. Jurnal Akuntasi, Vol. 4 No. 1

Pesiwarissa, P. (2014). Analisis Pengaruh DER, ROE, dan EPS Terhadap Nilai Perusahaan. Jurnal Manajemen, Akuntansi dan Studi Pembangunan, Vol 13 No 2.

Prasetyorini, B, F. (2013). Pengaruh Ukuran Perusahaan, Leverage, Price Earning Ratio dan Profitabilitas Terhadap Nilai Perusahaan. Jurnal Ilmu Manajemen, Volume 1, No 1

Priatinah, D. \& Kusuma, P. A. (2012). Pengaruh Return On Investment (ROI), Earning Per Share (EPS) dan Dividen Per Share (DPS) Terhadap Harga Saham Perusahaan Pertambangan yang Terdaftar di Bursa Efek Indonesia Periode 2008-2010. Jurnal Nominal. Volume 1, No 1

Sawir, A. (2001). Analisis Kinerja Keuangan dan Perencanaan Keuangan Perusahaan. Jakarta: PT Gramedia Pustaka Utama.

Sari, P. D. \& Hidayat, R. (2014). Pengaruh Net Profit Margin dan Return on Assets Terhadap Harga Saham Pada Perusahaan Otomotif yang Terdaftar di Bursa Efek Indonesia. Jurnal Akuntasi. ILMAN, Vol.1, No.1, pp. 110 ,

Saerang, D. P. E., Tulung, J. E., \& Ogi, I. W. J. (2018). The influence of executives' characteristics on bank performance: The case of emerging market. Journal of Governance \& Regulation, 7(4), 13-18.

Sorongan, F. A. (2016). Factors Affecting the Return Stock Company in Indonesia Stock Exchange (IDX) LQ45 in Years 2012-2015. The Winners, 17(1), 37-45. 
Sunandes, A. (2013). Pengaruh NPM, ROI, ROE, EPS Terhadap Harga Saham Pada Perusahaan Otomotif dan Komponen yang Terdaftar di Bursa Efek Indonesia. Jurnal Kompilek, Vol. 5 No. 2, Hal 64-156.

Syamsuddin, Lukman. (2007). Manajemen Keuangan Perusahaan: Konsep Aplikasi dalam Perencanaan Pengawasan, dan Pengambilan Keputusan. Jakarta: PT. Raja Grafindo Persada.

Tulung, J. E., Saerang, I. S., \& Pandia, S. (2018). The influence of corporate governance on the intellectual capital disclosure: a study on Indonesian private banks. Banks and Bank Systems, 13(4), 61-72.

Tulung, J. E., \& Ramdani, D. (2018). Independence, size and performance of the board: An emerging market research. Corporate Ownership \& Control, 15(2-1), 201-208.

Tulung, J.E. (2017). Resource Availability and Firm's International Strategy as Key Determinants Of Entry Mode Choice. Jurnal Aplikasi Manajemen, 15(1), 160-168.

Tulung, J. E., \& Ramdani, D. (2015). The Influence of Top Management Team Characteristics on BPD Performance. International Research Journal of Business Studies, 8(3), 155-166.

Widarjono, A. (2013). Ekonometrika: Pengantar dan Aplikasinya Disertai Panduan Eviews. Yogyakarta: UPP STIM YKPN.

Zunaini, E \& Brahmayanti, I. A. (2016). Pengaruh Rasio Likuiditas Diukur Dengan CR, QR dan Rasio Profitabilitas Diukur dengan ROA, ROE Terhadap Return Saham di Perusahaan Otomotif Periode 2012-2014 di Bursa Efek Indonesia. Jurnal Ekonomi Manajemen, Volume 1, Nomor 1 Hal 45 - 60 